\title{
FOOD HOARDING BEHAVIOUR OF PIKA (OCHOTONA) IN LANGTANG NATIONAL PARK, NEPAL
}

\author{
NARAYAN P. KOJU' AND MUKESH K. CHALISE ${ }^{1} \otimes$ \\ ${ }^{1}$ Central Department of Zoology, Tribhuvan University \\ Kirtipur, Kathmandu, Nepal \\ mukesh57@hotmail.com
}

\begin{abstract}
The study was conducted on food hoarding behaviour of pika in Langtang National Park (LNP). It was carried along transect of $53 \mathrm{Km}$ length and 200m wide from 3000 masl to 5200 masl in two routes (Langtang route and Gosainkunda route) from 2011 to 2013. Behaviours of pika were recorded from 5:30 to 19:30 during summer and from 6:30 to 17:30 during winter using focal scan sample method. Total 684 hours behaviours were recorded in 129 days covering all the seasons. Seven dry hay-piles were observed and 12 incidents of transferring food were observed. Pikas in Langtang were very poor in food hoarding and this behaviour was observed only in subalpine area.
\end{abstract}

Keywords: Pika, subalpine, hay-pile, Langtang, Nepal

\section{INTRODUCTION}

Food hoarding is an important component of adaptive strategies of many animals. The benefits derived from hoarding food include improving individual's chance of surviving period during food scarcity, allowing animals to optimize foraging and improving feeding criteria and enhanced animal's competitive status when forage for limited resource (Vander Wall, 1990). Pikas are generalist herbivore; they usually feed plants in two ways: instant feeding after cutting plants or their parts and transferring the feeding materials to construct hay-pile for winter usage. In instant feeding, pika feed again in two ways; if the plant is small and its leaves or other consuming parts would small and delicate, it feeds at the plant uprooted site (Koju et al., 2013a). Pikas have high energetic demands than other mountain mammals (Kawamichi, 1976) as they do not hibernate, so they make multiple trips to collect plants and its parts during summer seasons (Beever et al., 2003). Their daily caloric intake is equivalent to filling their stomach nine times in a day. Food intake is found to increase during pregnancy and lactation period (Smith \& Weston,1990).

The distribution of pikas depend directly on the availability of forage plant species (Kawamichi, 1968; Bhattacharya et al., 2009). Pikas forage on various plant species. Koju et al. (2011) reported that 42 plants species consumed by pika in Gosainkunda route of Langtang National Park during rainy season. Those plants include herbs, shrubs and fruits. Khanal et al. (1999) reported that 33 plant species were found collected in their hay-piles in Bajura, far west Nepal. They spend around 23-25 percent of external time budget in feeding.

The hay-piles provide shelters to birds, lizards and insects and also help to increase in plant 
diversity by distributing seed and plants in microhabitat condition around the vicinity of the hay-piles (Primack,1998). Various evidences have shown a good relation of livestock to pika's hay-piles. The domestic cows and horses generally locate Pika's hay-piles and start feeding the hays deposited there. This generally happens in winter when the pasture land is covered with snow (Melnikov,1974). Shrews (Sorex species), the insectivorous small mammal generally hunt Pika's hay-piles for their diet in alpine region to feed upon insects present there (Naumov,1974). Pikas act as allogenic ecosystem engineers through the formation of hay-piles that accelerate soil development and increase fertility in low productivity alpine and subalpine talus and boulder fields, where soils are often shallow, alkaline, and nitrogen impoverished (Mattson,1980).

During late summer and early fall (July-September) haying starts with collecting of available meadow vegetation and storing them in their talus territories. It made up almost $55 \%$ of the pikas' surface activity. Pika stops carrying plant materials after haying sufficient amount and continues feeding until the ground is covered with snow. Haying ceased in such environment as absence of surface vegetation due to covered by snow. Pika individuals remain under snow packed feeding on vegetation from their hay-pile's at the beginning of February, and they also use lichens available below the snow. Surface activity was not seen again until May when spring vegetation begin to appear (Conner,1983). In Colorado, USA, a Ochotona princeps population had the average hay-pile size $28 \mathrm{~kg}$ of fresh vegetation which represents 14,000 foraging trips during 8-10 weeks of the summer (Dearing,1997).

\section{Study area}

Langtang National Park (LNP) is located in the central Himalayas of Nepal between $85^{\circ} 15^{\prime} \mathrm{E}$ to $86^{\circ} 0^{\prime} \mathrm{E}$ and $28^{\circ} 20^{\prime} \mathrm{N}$ to $28^{\circ} 32^{\prime} \mathrm{N}$. The Park headquarter is of $132.2 \mathrm{~km}$ in road distance form Kathmandu the capital city of Nepal. The park covers $1710 \mathrm{~km}^{2}$ area. The Langtang National Park (fig. 1) harbours 46 mammalian species. Langtang Lirung $(7245 \mathrm{~m})$ is highest point in the park. Langtang National Park was officially established in March 1976. Its land area includes three districts of Nepal, Rasuwa, Nuwakot, and Sindhupalchowk (DNPWC, 2013). The complex topography and composition of geology reflect the wide spectrum of vegetation type which range from $1000 \mathrm{~m}$ elevation to alpine region. Many plant species are endemic to Nepal such as Rhododendran cownanaianum, R. lowndesii, and Picea smithiana. It has small area of subtropical forest with predominantly sal species (Shorea robusta) just below $1000 \mathrm{~m}$ and covers the hill. Oaks, Chirpine, Mapple, fir, Blue pine, Betula, Bamboo, Hemlock, Spruce and various species of Rhododendrons are main forest species. Above there, alpine shrubs and grasses give way to rock and snow. The snowline in LNP lies at $5000 \mathrm{~m}$ above sea level while tree line is around 4500m (Kawamichi, 1968).

The forest types range from sub-tropical to alpine tundra vegetation. Larix (Larix himalaica), Oak (Quercus semecarpifolia), Chirpine (Pinus roxburghii), Maple (Acersp.), Fir (Abies spectabilis), Blue pine (pinus wallichiana), Hemlock (tsuga dumosa), Spruce, many colorful flowering species like Gentiana, Primula, Saxifraga and various species of Rhododendron constitute the floral elements. This park accommodates significant faunal components like Snow leopard (Uncia uncia), Red panda (Ailurus fulgens), Musk deer (Moschus chrysogaster), Himalayan thar (Hemitragus jemlahicus), many birds and butterfly species (Chalise, 2010). 


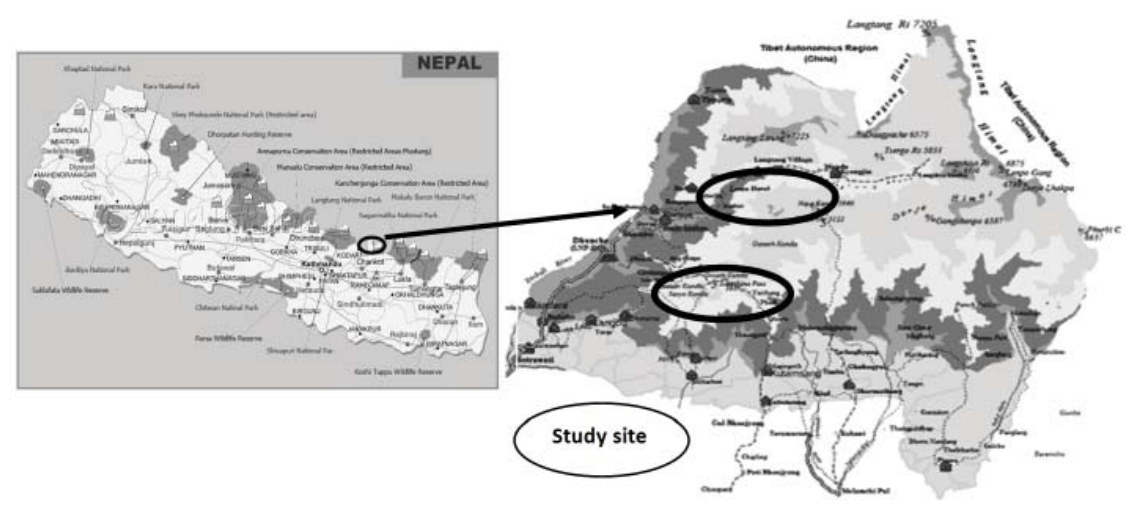

FIG. 1. Map of study area, Langtang National Park, Nepal.

\section{MATERIALS AND METHODS}

The study was conducted along transect of $53 \mathrm{~km}$ length and $200 \mathrm{~m}$ wide from 3000 masl to 5200 masl in two routes (Langtang route and Gosainkunda route) from 2011 to 2013. The behaviours of pika was observed and recorded by using focal scan sampling (Altmann, 1974) in time interval of one minute. Behaviour of pikas were observed from 5:30 to 19:30 during summer and from 6:30 to 17:30 in winter. Observation was done standing on vantage point. Binocular were used as required. During such observation the hoarding behaviours of pika was noted distinctly. The identified hay-piles were listed and the composition of plants in each haypile were recorded.

\section{RESULTS}

Two species of pikas: Ochotona roylei and O. macrotis were observed in Langtang National Park. The behaviours of both the species of pika was observed/recorded for 684 hours during this study. On this total time, behaviour of Ochotona macrotis was observed for 459 hours covering 294 hours in summer and 165 hours in winter. External behaviour was recorded for 186.16 hours $(63.32 \%$ of total time) and 18.38 hours $(11.14 \%)$ respectively. Similarly, behaviour of Ochotona roylei was recorded for 155.2 hours and 32.1 hours with the percentage of activeness $68.98 \%$ and $14.27 \%$ respectively in summer and winter seasons.

The instant feeding of pika again differentiate in two ways; if the plant was small and its leaf or other consuming parts were small and delicate, it feeds at the plant uprooted site especially plants like Sterallia alsine, Fragaria nubicola, Bistorta affinis, Moss, lichens, Poa species, Gramineae species, Potentilla species, Fragaria species, Juncus thomosnii and others. These small sizes plants were consumed directly whole part without tearing them in smaller parts. Plants which are larger in size, with broad and large leaf; pika tears the leaf or cut the petiole and carry it to a few distance near big rock or open ground and feed there. After consumption carried plant parts, pika again repeat cutting the large part of plant similar way and move to same place for feeding

In study period both species of Pikas (Ochotona roylei and Ochotona macrotis) in Langtang were 
not active in storing hay-pile. Only seven hay-piles were observed during winter season with dry vegetation of Juncus thomosnii, Fragaria species, Argmone species, Ligularia ampllexicaulis, Artimisia vulgare, Poa species, Rumex nepalensis, Graminae species, and some very dry plant species that were unidentified (Fig 2).
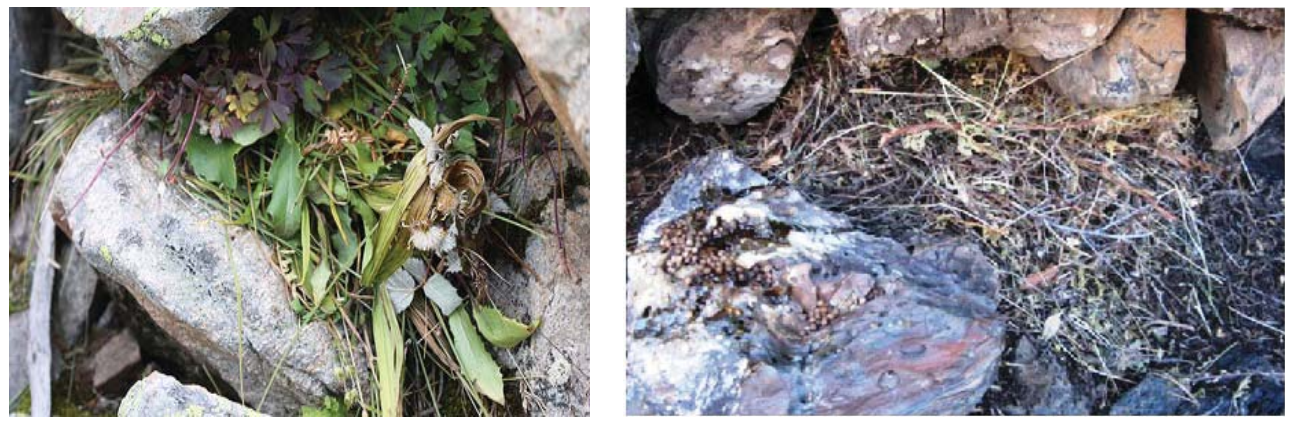

FIG. 2. Fresh hay-pile in summer/ rainy and dry hay pile in winter in LNP.

Only Royle's pika (Ochotona roylei) was found at forest and its edge area and they were never observed carrying forage for winter hay-pile in any season. The transferring foods by pikas in Langtang were not observed above 3900 masl too. In rainy and summer season behaviour of transferring food were observed only for 12 times in 449 hour observation (fig. 3). They were recorded three times in Thadepati, six times in Phedi, one in Laurebina area and two in Langtang valley. All these area were in subalpine area with broken rocks above 3500 masl and below 3900 masl. Among these observations only two incidents were belonged to O. macrotis in Phedi.
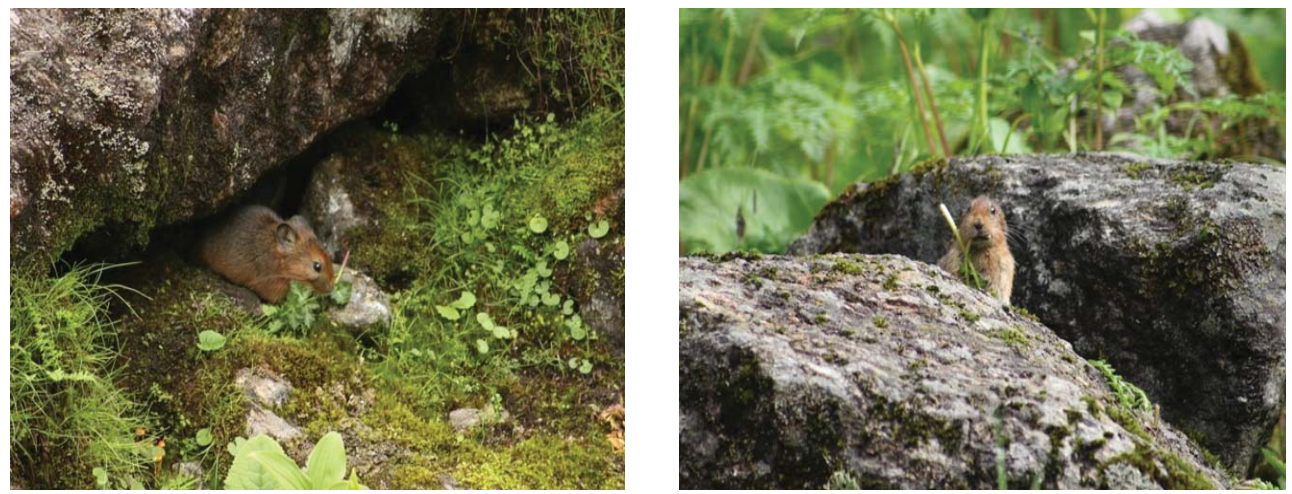

FIG. 3. Pika carrying plants to construct hay-pile for winter storage.

Fresh hay-pile contained Fragaria species, Potentilla species, Primula species, Ligularia ampllexicaulis, Gramineae species, Juncus species, Rumex nepalensis and Poa species (fig. 2). These all plants were consumed in highest frequency in subalpine habitat. The compositions of plants do not depend on sizes of plants. Pikas store and feed almost all plants which are available there as ground vegetations. 


\section{DISCUSSION}

Food hoarding or constructing hay-pile is another special character of pika to escape or avoid the inaccessibility of food in harsh season of the year. It is one of the adaptations for supply of winter food when habitat is usually covered by snow. In Khumbu, Sagarmatha (Mt. Everest) region food hoarding was never observed during winter by Ochotona macrotis and O. roylei. A single exception was a small hoard consisting of 14 plants pieces probably of $O$. macrotis found on $27^{\text {th }}$ December, 1971 (Kawamichi, 1971a;1971b). In Api Nampa area Koju \& Chalise (2013) reported the observation of a single old hay-pile with old pellets in 2012 which consisted five species of forage plants, two were from Poaecae family, Fragaria species, Potentilla species and Rumex species. The hay-pile materials were very dry and de-structured so further detail could not reveal. There was not any hay-pile recorded in the same season of successive years (Koju \& Chalise, 2013). Khanal \& Shrestha (2000) did not report about presence of hay-pile in Langtang but Khanal et al. (1999) reported 33 species of plants deposited in hay-pile of Royle's pika among 48 species of plants found around their home range in Bajura, far western region of Nepal. Abundance of Royle's pika of Uttarkhanda, Bhattacharya et al. (2009) reported very low hoarding capacity of pika. The scarcity or virtual absence of hoarding behaviour in O. macrotis and O. roylei is noteworthy (Kawamichi, 1971a;1971b). Similar report on absence of hoarding behaviour observed by Bernstein (1970) on O. macrotis of Tien-Shan Mountains, China.

Ochotona hyperborean yesoensis in northern Japan starts hoarding food for winter from late July to October and American pika (Ochotona princeps) start a month early June to October (Kawamichi, 1985). Ochotona princeps spends a considerable amount of time during summer caching vegetation. These caches (hay-piles) have been suggested to function as diet in winter and source of food for intermittent periods when the animal is unable to forage elsewhere, or in nonfood functions, e.g., nest sites (Dearing, 1997). O. princeps are asocial (Morrison, 2006) does not cooperate to build other's hay-pile. They were observed making up to 13 trips/hr for haying (Beever et al., 2003).

Travina (1984) calculated that even at a modest density of ten to twelve pikas per hectare, storage amount of vegetation by pikas may up to $30 \mathrm{~kg} / \mathrm{hec}$ in Afgan pika (Ochotona rufescens). The stores of a Afghan pika may content up to 58 species of plants and weigh up to $5 \mathrm{~kg}$ (Sapargeldyev, 1987) remain exposed above the surface of the snow. Daurian pika (Ochotona daurica) accumulate hay-pile at the entrance (Kawamichi \& Dawanyam, 1997) which they use mostly in breeding season for breeding purpose (bed) and also use as food in winter. Ochotona curzoniae, ecologically similar species to 0 . daurica also store hay-pile in its burrow which is most often used by different birds and mammals as source of insulation in winter and simultaneously used for food by pika (Smith \& Foggin, 1999; Lai \& Smith, 2003).

Dearing (1996) recorded that Ochotona princeps hording selection depend on morphology of plants. They prefer large size plants species for hay-pile. Leaf morphology and size effect in selection of food was also explained by Bhattacharyya et al. (2013) in his research of Ochotona roylei. Aho et al. (1998) had explained pikas as allogenic engineer of alpine ecosystem. Their team found that hay-pile soils had significantly higher carbon and nitrogen levels and lower $\mathrm{C} / \mathrm{N}$ ratios than both adjacent soils and soils in the general study area. Su et al. (2003) had 
explained on behaviour of hoarding hay-pile by Gansu pika (Ochotona cansus) in Gansu, China, observing 27 hay-piles in late fall of the year from meadow. In the Chelyk-Khem River valley, Travina et al. (2000) explained that Altai pikas begin to store plants between July 10 and October 21, a week earlier than northern pikas. A family of pikas in that place usually makes two to seven stores (stacklets) located 1-3 meters apart from one another in the same places from year to year. Broadbooks (1965) explained that Ochotona collaris from Washington State, USA are very active in hoarding hay-pile and they stored $40 \%$ of plants species available in their habitat. Field observations of Holmes (1991) made on Ochotona collaris, in Alaska determined that these pikas do hoarding food even though high risk of predation during foraging, they donot travel more than 10m for forage. Similar findings were explained by Morrison et al. (2004), which explained that due to predation risk, Ochotona collaris store poor quality food for winter.

In current research, both species of pikas in Langtang area were found not active in storing haypile. Only seven hay-piles were observed during winter season. O. roylei was found transferring and hoarding forage for nine times and 0 . macrotis for only two times. All the haypiles and food transferring incidents were observed only in subalpine area. Thus, there is very weak food hoarding nature in pikas in Langtang and absence of food hoarding behaviour in forest dwelling and alpine talus dwelling pikas. The adaptation in this behaviour may be due to predation risk or sufficient alternative food availability for winter too. The foraging behaviour and haying nature of those two species as well as other species of pikas in Nepal is still unexplored in detail.

\section{ACKNOWLEDGEMENTS}

We would like to thank Mr. Rajendra Chawal, Anil Shrestha and Bal Krishna Banmala who helped us in the field work. We extend thank to Second Higher Education Programme (SHEP) fellowship programme, University Grant Commission, Sano Thimi, Nepal providing fund to conduct this research. We are thankful to Central Department of Zoology, Tribhuvan University for cooperation and Department of National Park and Wildlife Conservation Babarmahal and Langtang National Park for providing permission to conduct the research in the National Park.

\section{REFERENCE}

Aho, K; Huntly, N; Moen, J; Oksanen, T (1998) Pikas (Ochotona princeps: Lagomorpha) as allogenic engineers in an alpine ecosystem. Oecologia, 114(3): 405-409.

Altmann, J (1974) Observational study of behaviour: sampling methods. Behaviour 227-267.

Beever, E A; Brussard, P F; Berger, J (2003) Patterns of apparent extirpation among isolated populations of pikas (Ochotona princeps) in the Great Basin. Journal of Mammalogy 84(1): 37-54.

Bernstein, A D (1970) The ecology of large eared pika in the Tien-Shan. Fauna and ecology of Rodent 9: 62-109.

Bhattacharya, S; Adhikari, B S; Rawat, G S (2009) Abundance of Royle's pika (Ochotona roylei) along an altitudinal gradient in Uttarakhand, western Himalaya. Hystrix, the Italian Journal of Mammalogy 20(2):111-119.

Bhattacharyya, S; Adhikari, B S; Rawat, G S (2013) Forage selection by Royle's pika (Ochotona roylei) in the western Himalaya, India. Zoology 116(5): 300-306.

Broadbooks, HE (1965) Ecology and distribution of the pikas of Washington and Alaska. American Midland 
Naturalist 73: 299-335.

Chalise, M K (2010) A study of Assamese monkey in Sebrubeshi of Langtang National Park, Nepal. Journal Natural History Museum 25: 54-61.

Conner, D A (1983) Seasonal changes in activity patterns and the adaptive value of haying in pikas (Ochotona princeps). Canadian Journal of Zoology 61(2): 411-416.

Dearing, M D (1996) Disparate determinants of summer and winter diet selection of a generalist herbivore, Ochotona princeps. Oecologia 108(3); 467-478.

Dearing, M D (1997) The function of hay piles of pikas (Ochotona princeps). Journal of Mammalogy 78:1156-1163.

Holmes, W G (1991) Predator risk affects foraging behaviour of pikas: observational and experimental evidence. Animal Behaviour 42(1): 111-119.

Kawamichi, T (1968) Winter behaviour of the Himalayan pika (Ochotona roylei). J Hkkaido University. Fac. Sci Zoology VI(16): 582-554.

Kawamichi, T (1971a) Annual cycle of behaviour and social pattern of the Japanese pika, Ochotona hyperborea yesoensis. J. Fac. Sci. Hokkaido Univ. Ser. VI Zool 18: 173-185.

Kawamichi, T (1971b) Daily activities and social pattern of two Himalayan pikas, Ochotona macrotis and O. roylei, observed at Mt. Everest. Journal of the faculty of Science Hokkaido University Series VI. Zoology 17(4): 587-609.

Kawamichi, T (1976) Hay territory and dominance rank of pikas (Ochotona princeps). Journal of Mammalogy 57/1:133-148.

Kawamichi, T. (1985) Behaviour and social organization of five species of pikas and their evolution. In Kawamichi, T (ed) Contemporary Mammalogy in China and Japan, Mammalogical Soci., Japan; pp. 43-50.

Kawamichi, T; Dawanyam, S (1997) Structure of a breeding nest of the Daurian pika, Ochotona daurica, in Mongolia. Mammal Study 22: 89-93.

Khanal, B; Shrestha, K (2000) Habitat preferences by Royle's pika (Ochotona roylei) in Gosainkund, Rasuwa district of central Nepal. Journal of Natural History Museum 19: 27-33.

Khanal, B; Shrestha, K; Karki, J B (1999) Foraging and haying plants of Royles pika (Ochotona roylei: Lagomorpha) in far west Nepal. Journal of Natural History Museum 18: 3-13.

Koju, N P; Chalise, M K (2013) Royle's pika (Ochotona roylei) observation in Api Nampa Conservation area, Nepal. Journal of Natural History Museum 27: 78-86.

Koju, N P; Chalise, M K; Kyes, R C (2011) Ecology of pika (Ochotona species) in Gosainkunda area, Langtang National Park, Nepal. Paper presented at the Science Vision, Mizoram.

Koju, N P; Chalise, M K; Kyes, R C (2013a) Ecology of pika (Ochotona species) in Gosainkunda area, Langtang National Park, Nepal. In Khanna, D R; Solanki, G S; Pathak, S K (eds) Environment, biodiversity and traditional System. Biotech Books, India; pp. 75-86.

Koju, N P; Chalise, M K; Kyes, R C (2013b) Forage selection and conservation threats on pika (Ochotona species) at Gosainkunda area, Langtang National Park. Wildlife Week, (DNPWC/Govt. of Nepal) 18: 33-41.

Lai, C H; Smith, A T (2003) Keystone status of plateau pikas (Ochotona curzoniae): effect of control on biodiversity of native birds. Biodiversity \& Conservation 12(9): 1901-1912.

Mattson, W J (1980) Herbivory in relation to plant nitrogen content. Annual review of ecology and 
systematics 11:119-161.

Melnikov, V K (1974) On the ecology of Ochotona alpine pall in the western Sayan Mountains. Byull. Mosk. Obsh. Ispytat. Prirody, Otd. Biol, 79: 141-142.

Morrison, S (2006) Foraging ecology and population dynamics of collared pikas in southwestern Yukon. Arctic. 59(1): 104-107.

Morrison, S; Barton, L; Caputa, P; Hik, D S (2004) Forage selection by collared pikas under varying degrees of predation risk. Canadian Journal of Zoology 82(4): 533-540.

Naumov, R L (1974) Ecology of Ochotona alpine in the west Sayan. Zool.Zh. 53: 1524-1529.

Primack, R B (1998) Essential of conservation biology (Vol. 2). Sinauer Inc., Massachusetts, USA.

Sapargeldyev, M (1987) Ecology of the Afghan pika in Turkmenistan Ashkhabad. 144 pp.

Smith, A T; Foggin, J M (1999) The plateau pika (Ochotona curzoniae) is a keystone species for biodiversity on the Tibetan plateau. Animal Conservation 2(4): 235-240.

Smith, A T; Weston, M L (1990) Ochotona princeps. Mammalian Species 352: 1-8.

Su, J; Lian, X; Zhang, T; Cui, Q; Liu, J (2003) Hay pile caches a winter food by Gansu pikas and its biological significance. Acta theriologica sinica 24(1): 23-29.

Travina, I; Derviz, D; Dmitriev, P (2000) Relationships between pikas (Ochotona, mammalia) and vegetation in Tuva. Russian Journal of Ecology 31(1): 36-42.

Travina, I V (1984) Influence of pikas on the vegetation of southern Tuva. Department of Vertebrate Zoology, Moscow State University, Moscow; 82 pp.

Vander Wall, S B (1990) Food hoarding in animals. The University of Chicago Press, Chicago, USA. 